\title{
Occurrence of Fungi in Drinking Water Sources and Their Treatment by Chlorination and UV-Irradiation
}

\author{
Eman A.M. Ali\#, Tahany M.A. Abdel-Rahman, Mohsen Abo-Ela Sayed and \\ Samar H. Abd Al Khalek \\ Department of Botany and Microbiology, Faculty of Science, Cairo University, Giza, \\ Egypt.
}

\begin{abstract}
$\mathbf{A}^{\mathrm{T}}$ TOTAL of $54 \mathrm{cfu} / \mathrm{ml}$ fungal species were isolated from 9 water samples collected from Nile water, Water Treatment Plant (WTP) and tap water in many governorates in Egypt. The fungal species Aspergillus alutaceus, A. flavus, A. fumigatus, A. niger, A. sulfurous, A. terreus, Penicillium chrysogenum, P. globrum and Trichoderma viride were isolated from water samples. Nile water $\left(\mathrm{S}_{1}\right)$ was polluted with the highest fungal count and diversity followed by treated tap water in Al Sharqia $\left(\mathrm{S}_{5}\right)$ Governorate. The physicochemical analysis revealed higher COD and conductivity in Al Sharqia tap water sample than that in untreated Nile water sample which may be due to the old rusted distribution systems or heavy metals contamination. Laboratory scale treatment of tap water in Al Sharqia sample $\left(\mathrm{S}_{5}\right)$ indicated that single treatment with chlorination was not efficient to eliminate fungal contamination except by using high chlorine concentration with long exposure time. Similarly single UV treatment to drinking water was not effective enough. Combination between UV irradiation followed by chlorination exerted synergistic effect and disinfected water from fungal contamination in very short exposure time and very low chlorine concentration.
\end{abstract}

Keywords: Water treatment pPlant (WTP), Drinking water, Water fungi, Physicochemical analyses, Chlorination, UV irradiation.

\section{Introduction}

The World Health Organization (WHO) defines safe water for human consumption as "water that causes no any significant hazard to human health during consumption". Contaminations with pathogenic microorganisms are one of the greatest concerns for the consumers of water with respect to the quality of drinking water (Oliveira et al. 2013).

Some microorganisms, like various bacteria, viruses and parasites are known as water contaminants that may cause waterborne diseases and epidemics. With respect to the quality of drinking water, bacteria are the most studied group of microorganisms. Studying the presence of pathogenic viruses in water is also important, as viruses are the most common cause of gastrointestinal infections worldwide
(Mara \& Horan 2006). In the past, fungi were rarely considered during studying of pathogenic microorganisms that found in water. A possible reason for this is that the presence of pathogenic bacteria, viruses and parasites in drinking water commonly lead to relatively acute symptoms and diseases in humans. Limited attention has been given to the fungal occurrence (filamentous fungi and yeasts) in aquatic environment (Dogget, 2000; Arvanitidou et al., 2002; Hageskal et al., 2006 and 2007). So, research is needed in this area since waterborne fungi could also be associated with health related effects as skin irritations and allergic reactions, as well as an increased occurrence of opportunistic systematic mycosis in immunocompromised patients. Waterborne fungi may also responsible for taste and odour problems and contamination in food and beverages (Spreadbury et al., 1993; Dogget, 
2000; Anaissie et al., 2001; De Hoog et al., 2004 and Bucheli et al., 2008). Furthermore, aflatoxins (G2 and B2) that produced by Aspergillus flavus have been detected in stored water (Paterson et al., 1997). Recently, attention has been drawn to the presence and identification of fungi in drinking water sources, bottled mineral water, tap water and water distribution systems (Göttlich et al., 2002; Cabral \& Pinto 2002; Kanzler et al., 2007; Yamaguchi et al., 2007; Hageskal et al., 2006, 2008, 2009 and Pereira et al., 2009).

Fungi are a diverse group of organisms that belonging to the kingdom Eumycota (Kirk et al., 2001 and Schüßler et al., 2001). Some fungi are primarily adapted to aquatic environments, so they naturally found in water. Others are primarily adapted to terrestrial environments. They are found in organic material, soil, air and anything in contact with air (Kirk et al., 2001). These fungi may also enter drinking water from several sources, although water is considered as 'unnatural' habitat for them (Hageskal et al., 2009). Pereira et al. (2009) reported the presence of 49 fungal species in drinking water, most of them were firstly determined in water sources. He also expected the high occurrence of fungi in drinking water sources due to their broad occurrence in the environment. Presence of fungi in distribution systems was also studied (Dogget, 2000 and Hageskal et al., 2007). Bacteria, filamentous fungi, and yeasts were reported in three different sources of drinking water using new techniques and media with different composition of matrix for fungal isolation from water sources (Pereira et al., 2009 and 2010).

In the past sand filtration was used for water treatment. Water borne disease is still a problem elsewhere if systems are unmanaged after treatment (Domingo et al., 2015). Application of free chlorine to disinfect drinking water is used broadly to inactivate a wide range of microorganisms and has conserved numerous lives from water borne diseases (Galal-Gorchev, 1996 and Baron et al., 2014). Fungal conidia were more resistant to chlorine disinfections than yeasts and coliform bacteria, so they may survive water treatment and colonize distribution systems (Rosenzweig et al., 1983 and Ma \& Bibby, 2017). Hageskal et al. (2006, 2007) characterize the chlorinated Norwegian drinking water with the presence of numerous fungi and deduced that the water mycobiota should be considered at estimation of the microbiological safety and drinking water quality. In United States, 25 drinking water samples were collected and assayed for presence of pathogens before and after treatments with chloramines and ozone. Protozoa, fungi, and bacteria were present in samples. Aspergillus fumigatus was detected in high frequency in water samples before treatment but absent after treatment (King et al., 2016). Fungal species displayed different degrees of resistance towards free chlorine disinfection (Pereira, 2013). The resistant species were Cladosporium tenuissimum, Cladosporium cladosporioides, Phoma glomerata, Aspergillus terreus, Aspergillus fumigatus, Penicillium griseofulvum and Penicillium citrinum. Codony et al. (2005) reported that inactivation efficiency against the biofilm formation did not recover when chlorine returned to normal levels after chlorine neutralization.

The effectiveness of UV irradiation in the disinfection of some Water Treatment Plants (WTP) had been reported (Nourmoradi et al., 2012). They studied the effect of UV irradiation on some Aspergillus species. UV irradiation can be effective in inactivation of spores of A. flavus, Penicillium corylophilum, Eurotium rubrum and Aspergillus niger in water with various degrees according to fungal genera and methods of exposure (Begum et al.2009).

The present research was planned to isolate, count and identify fungal genera and species contaminating drinking water samples collected from different governorates in Egypt. Laboratory scale experiment was done using single chlorination or UV irradiation and their combination to disinfect selected water samples. Physicochemical parameters were analyzed in treated sample and compared with Nile water.

\section{Materials and Methods}

Water sampling

Three sampling types of water were collected:

i. Nile water sample $\left(\mathrm{S}_{1}\right)$ before treatment (control).

ii. Drinking water sample $\left(\mathrm{S}_{2}\right)$ after treatment in Dar El Salam Water Treatment Plant (WTP) and before distribution.

iii. Water samples taken from home taps after treatment and distribution $\left(\mathrm{S}_{3}\right.$ : Dar El Salam, $\mathrm{S}_{4}$ : Ain Shams, $\mathrm{S}_{5}$ : Al Sharqia, $\mathrm{S}_{6}$ : Banha, $\mathrm{S}_{7}$ : Al Qliobia, $\mathrm{S}_{8}$ : Al Khosos and $\mathrm{S}_{9}$ :Tokh). 


\section{Mycological survey and identification}

Pour plate method was used for isolation of water fungi using Sabouraud Dextrose Agar medium (SDA) (Kanzler et al., 2007; Hageskal et al., 2009 and Pereira et al., 2010) and Malt Extract Agar medium (MEA) (Hageskal et al., 2009 and Pereira et al., 2010). One $\mathrm{ml}$ of each water sample was placed into sterile Petridishes.Media were poured after adding Rose Bengal and Chloramphenicol, and incubated at $25-27^{\circ} \mathrm{C}$ for 7 days; colony forming units (cfu/ $\mathrm{ml}$ ) were counted.Isolated fungi from drinking water sources were identified morphologically and microscopically according to Moubasher (1993).

\section{Physicochemical analyses}

pH, COD, BOD, turbidity, phenol, nitrate content and conductivity

$\mathrm{pH}$ of the water sample was measured using pH electrode (WAT-03, CONSORT C932, Made in Belgium). Chemical oxygen demand (COD), Biological oxygen demand (BOD), turbidity, phenol and nitrate content were measured using the Nanocolor Technique (WAT-01, Photometer NANOCOLOR" 500 D) in Micro Analytical Center, Faculty of Science, Cairo University. Conductivity was measured using conductivity electrode (WAT-03, CONSORT C932, Made in Belgium).

\section{Oil and grease Measurement}

Dry conical flask with $25 \mathrm{ml}$ chloroform was weighed then $50 \mathrm{ml}$ of water sample were mixed and added in separating funnel. Chloroform layer was taken in the conical. The difference in weight was then calculated:

Oil + grease $=$ difference in weight of chloroform $\times 20 \times 1000$

Laboratory scale treatment of fungi isolated from water samples

It was done according to Al Gabr et al.( 2013)

\section{Chlorination}

Different concentrations of sodium hypochlorite solution, rangingfrom 0.5 to 4 $\mathrm{mg} / \mathrm{l}$, were used. Different contact times used in the investigation were as follows: $5,15,30,60$ and $120 \mathrm{~min}$. The volume of tap water sample used in glass flask was $100 \mathrm{ml}$. Ascorbic acid $(25 \mathrm{mg} / \mathrm{l})$ was used to quench chlorine.

After disinfection process, $1 \mathrm{ml}$ of each treated sample was plated in Petri-dish using poure plate technique and incubated at 25 $27{ }^{\circ} \mathrm{C}$ for one week and the fungal count was enumerated as $\mathrm{cfu} / \mathrm{ml}$ and identified.

\section{UV irradiation}

Irradiation was done for $1 \mathrm{ml}$ of drinking water sample for different contact times (15, $30,60,90,120,150$ and 180 seconds). Then the fungal contamination was enumerated as $\mathrm{cfu} / \mathrm{ml}$ and identified.

Combined UV and chlorination treatment

Combined treatment was done for tap drinking water sample which subjected to different UV exposure times for $(15,30,60$, 90 and 120 seconds) then, after each UV exposure time, sodium hypochlorite $\mathrm{NaClO}$ concentrations $(1,0.5,0.25$ and $0.125 \mathrm{mg} / \mathrm{L})$ were applied in the sample for $30 \mathrm{~min}$ before adding ascorbic acid. UV irradiation applied first before chlorination to avoid oxidation of $\mathrm{NaClO}$ by UV. The fungal count was surveyed as $\mathrm{cfu} / \mathrm{ml}$ and identified.

\section{Results and Discussion}

Fungi are accepted as drinking water contaminants (Pereira et al., 2009 and Hageskal et al., 2009). Hence extensive researches about fungal occurrence, prevalence and their potential risk in drinking water were published. Fungi in drinking water have high ability to degrade complex natural and anthropogenic materials due to their high enzymatic activity (Fountoulakis et al., 2002; Yan \& Viraraghavan, 2003 and Junghanns et al., 2005). They may be pathogenic and mycotoxic to humans and plants (De Hoog et al., 2004 and Pereira et al., 2010).

In the present study isolation of fungi from water samples was done using two isolation media SDA and MEA (Table 1). MEA appeared more suitable for fungal isolation and caught 9 species taxa with frequency of $53.7 \%$ while SDA caught 5 species taxa with frequency of $46.3 \%$. Similar to our results, spread plate method using SDA and MEA are used by many investigators to detect drinking water fungi. But, difference in methodology of isolation makes direct comparisons hardly possible (Hageskal et al., 2008).

Table 1 and Fig. 1 revealed that a total of 54 fungal isolates represented by 9 fungal species were screened overall the study. Most of these isolates have never been described to occur in Egyptian drinking water sources. 


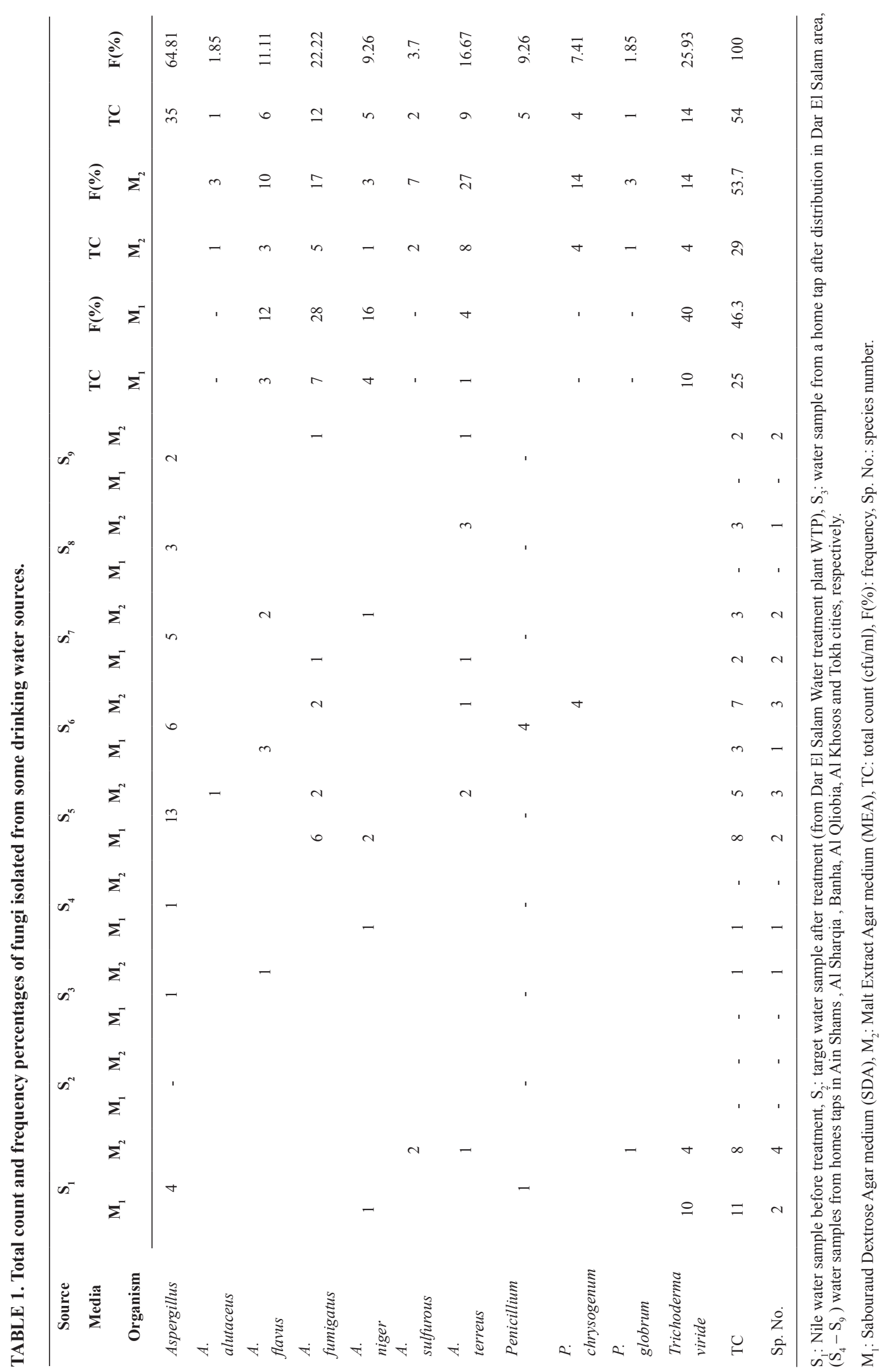

Egypt. J. Bot., 57, No.3 (2017) 


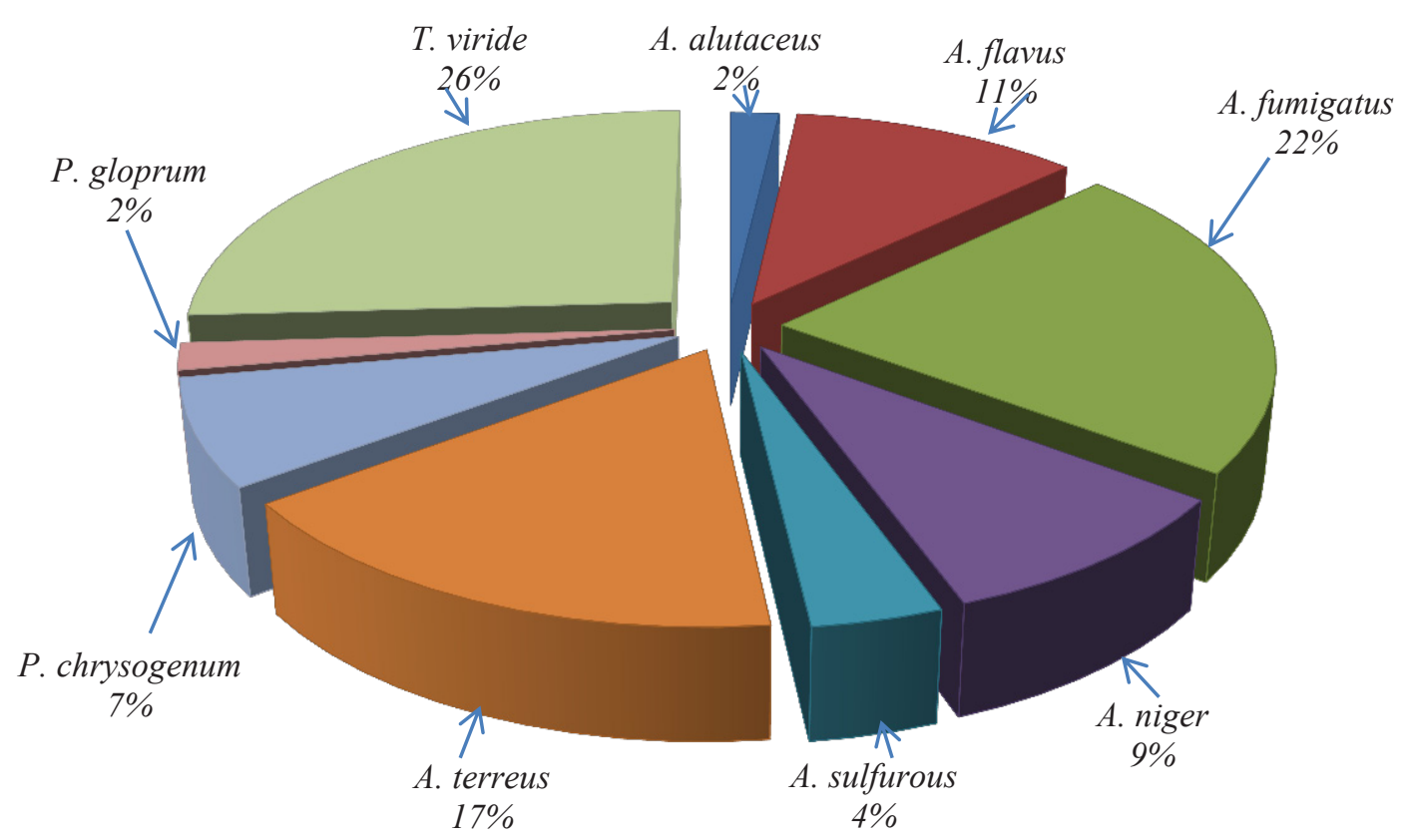

Fig. 1. Frequency percentages of fungal species isolated from some drinking water sources.

The genus Aspergillus was the most frequent taxa. It was represented by 35 isolates with frequency $64.81 \%$ constituted 6 species isolated from 8 of 9 samples. While, least dominant genus was Penicillium represented by 5 isolates constituting 2 species representing $9.26 \%$ frequency and screened from only 2 samples (Table 1).

Concerning fungal species, Trichoderma viride represented the most frequent species represented by 14 isolates with frequency percentage $25.93 \%$ of the total isolates. Aspergillus fumigatus came next with 12 isolates screened from four sites with frequency percentage $22.22 \%$ of the total count. Aspergilllus terreus came in the third rank with 9 isolates, distributed among 6 different water samples with frequency percentage $16.67 \%$ of the total isolates. However, the least dominant species were Aspergillus alutaceus and Penicillium globrum with 1 isolate each.

Figure 2 showed that Nile water sample before treatment $\left(\mathrm{S}_{1}\right)$ was the most polluted one with 19 fungal isolates of 54 containing 5 fungal species. However, the sample collected from home tap at Al Sharqia (Zagazig City), $\left(\mathrm{S}_{5}\right)$ came in the second rank of pollution containing 13 fungal isolates including 4 species. The third polluted sample was collected from home tap at Banha city $\left(\mathrm{S}_{6}\right)$ with 10 fungal isolates constituting 4 species. Moreover, water sample collected from water treatment plant (WTP) before distribution at Dar Elsalam city $\left(\mathrm{S}_{2}\right)$ was free of any fungal contamination indicated the efficiency of the treatment process. Furthermore, water sample collected, after distribution, from home tap at Dar Elsalam $\left(\mathrm{S}_{3}\right)$ and Ain Shams $\left(\mathrm{S}_{4}\right)$ cities were minimally contaminated (one fungal species each) denoting the efficiency of cleaning and maintenance of the distribution systems.

In close relation to our study, in Portugal Oliveira et al. (2013) found that Penicillium and Trichoderma were the most representative fungal genera in drinking water sources. Twenty four fungal species that had been not reported previously in aquatic environment were isolated. Memon (2012) found out of 40 samples, 36 samples were positive in fungi. Aspergillus, Penicillium, Absidia and Trichophyton dominated the samples of drinking water from distribution system in Hyderabad (Pakistan). Hageskal et al. (2009) and Pereira et al. (2009) detected prevalence of Aspergillus, Cladosporium, Penicillium and Candida in drinking water in Portugal and other countries. Aspergillus fumigatus was recovered from tap water samples taken from University of Oslo (Warris et al., 2001). Aflatoxin produced by Aspergillus flavus was detected in reservoirs and bottles stored for prolonged periods. Daily intake of mycotoxin contaminated water over many years lead to hazardous effects to human 
health (Paterson, 2006). Sauna water derived from taps was contaminated with Mucor, Absidia, Aspergillus fumigatus, Candida, Penicillium and Cladosporium. This water, consequently, caused allergy asthma and other respiratory problems (Straus, 2004 and Denning et al., 2006). Several studies found that fungal conidia were included in biofilms in water pipes surfaces (Dogett, 2000; Skaar \& Østensvik, 2005 and Paterson et al., 2006). So, attention should be considered to routine cleaning and maintenance of water distribution systems, pipes and showers especially in hospitals.

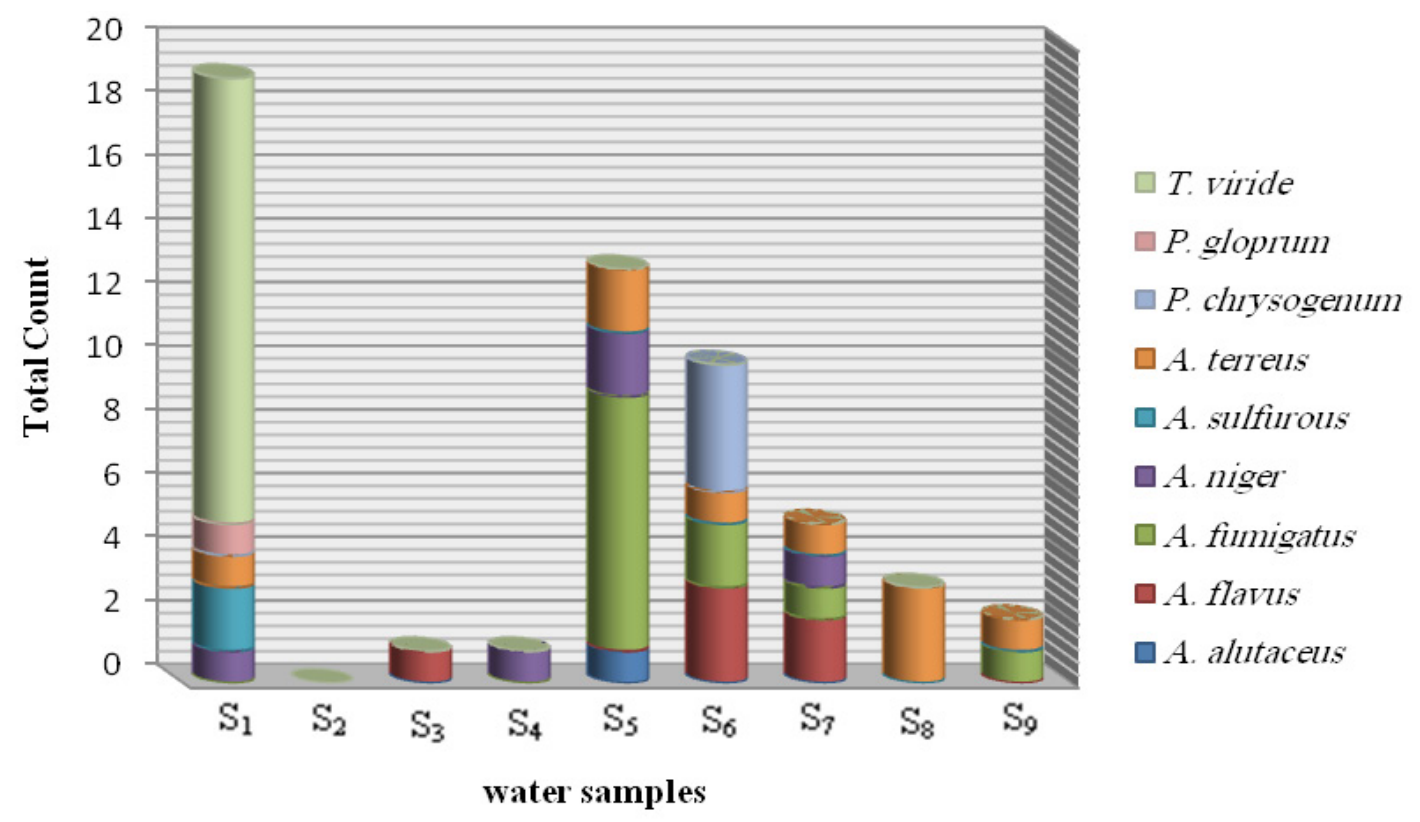

Fig. 2. Total count of isolated fungal species from water samples.

(S1) Nile water sample was taken before treatment. (S2) water sample after treatment was taken from Dar EI Salam WTP. (S3) water sample was taken from home tap after distribution.

Correlation between physicochemical parameters and the density and variation of fungi in the most polluted water samples $\left(\mathrm{S}_{1} \& \mathrm{~S}_{5}\right)$ were investigated (Table 2). Permissible limit in turbidity, $\mathrm{pH}$ and nitrate level were determined in both samples. However, COD, BOD, phenol and oil and grease exceed the permissible level in both samples. The treated tap water in Al Sharqia Governorate $\left(\mathrm{S}_{5}\right)$ recorded higher values than untreated Nile water $\left(\mathrm{S}_{1}\right)$ in each of COD and conductivity which may be due to either the old rusted pipes in distribution system or the presence of high heavy metals contaminants in drinking water (Sonigo et al., 2011).

Although Nile water contain higher oil \& grease and higher phenol contents than tap water, it colonized by greater fungal count than $\left(\mathrm{S}_{5}\right)$. Similarly, Pereira $(2009,2013)$ claimed that no significant correlation between levels of fungi detected in drinking water and physicochemical parameters.

Scientific investigations about the effective treatment against fungi are much more less than that of bacterial disinfection. So, in the present study we tried to treat water fungi in laboratory scale experiments using single chlorine or UV irradiation as well as combination between both of them.

Table 3 cleared the fact that the efficiency of treatment by chlorination was a function of its concentration and exposure time. Combination between high chlorine concentration and prolonged exposure time eliminated totally the fungal contamination from the tap water samples. $2 \mathrm{mg} / \mathrm{L} \mathrm{NaClO}$ with $15 \mathrm{~min}$ exposure time or 4 $\mathrm{mg} / \mathrm{L} \mathrm{NaClO}$ with $5 \mathrm{~min}$ exposure time were the most suitable treatment to disinfect tap water sample from fungal contamination. 
TABLE 2. Physicochemical analyses of home tap water sample $\left(\mathbf{S}_{5}\right)$ collected from (Al Sharqia) as compared with Nile untreated water sample $\left(\mathbf{S}_{1}\right)$.

\begin{tabular}{lccc}
\hline Parameter & $\mathbf{S}_{1}$ & $\mathbf{S}_{5}$ & Permissible limit \\
\hline $\mathrm{pH}$ & 7.70 & 7.50 & $6.5-8.5$ \\
C.O.D & $103(\mathrm{mg} / \mathrm{L})$ & $249(\mathrm{mg} / \mathrm{L})$ & Nil \\
B.O.D & $1.2(\mathrm{mg} / \mathrm{L})$ & $0.9(\mathrm{mg} / \mathrm{L})$ & $<1200$ \\
Conductivity & $372(\mu \mathrm{s} / \mathrm{cm})$ & $1227(\mu \mathrm{s} / \mathrm{cm})$ & $<1$ \\
Turbidity & $0.8(1 / \mathrm{m})$ & $<0.5(1 / \mathrm{m})$ & $<0.001$ \\
Phenol & $0.7(\mathrm{mg} / \mathrm{L})$ & $0.03(\mathrm{mg} / \mathrm{L})$ & $<45$ \\
Nitrate & $<0.9(\mathrm{mg} / \mathrm{L})$ & $<0.9(\mathrm{mg} / \mathrm{L})$ & Nil \\
Oil \& grease & $48(\mathrm{mg} / \mathrm{L})$ & $8(\mathrm{mg} / \mathrm{L})$ & \\
Fungal count & 19 & 13 & \\
(cfu/ml & & & \\
\hline
\end{tabular}

$\mathbf{S}_{1}$ : Untreated Nile water sample

$\mathbf{S}_{5}$ : Al Sharqia tap water sample

In this field, many authors suggested that chlorination used for disinfection of drinking water could not eliminate fungi completely (Nagy \& Olson, 1985 and Frankovà \& Horecka, 1995). The effect of free chlorine shows varying degrees of resistance. Some fungi are resistant as they protected from inactivation by matrix components or by biofilm they form (Periera et al., 2013). Fungi can be expected to occur densely in different water sources particularly those which contaminated by human wastes and occur also in water distribution systems (Dogget, 2000 and Hageskal et al., 2007). Chlorination of drinking water using high concentration of chlorine or exposure for prolonged periods create carcinogenic by-products such as trihalomethane, haloacetic acid, haloacetonitrile, etc (Kim et al., 2002). Conidia of fungi are very resistant to free-chlorine treatment and can survive in treated water and it is very possible to colonize the distribution systems (Rosenzweig et al., 1983). However, Periera et al. (2013) stated that chlorination effectiveness depends on the chlorine concentration, matrix parameters such as organic maters, suspended solids and exposure conditions such as $\mathrm{pH}$ and temperature.
In this study single UV-treatment was done. Table 4 revealed higher effectiveness of UV treatment to tap water samples $\left(\mathrm{S}_{5}\right)$ than chlorination. $30 \mathrm{sec}$ UV exposure eliminated about $90 \%$ of fungal contaminants. Higher than $30 \mathrm{sec}$ to $180 \mathrm{sec}, 100 \%$ disinfection of the polluting fungi in tap water samples was established. Similar to our results, Begum et al. (2009) claimed that UV- irradiation against fungal spores significantly varies depending on the method and the time of exposure used; as well as the exposed fungal species. UV- irradiation potentially controls the growth of Aspergillus flavus, Penicillium crylophilum, Eurotium rubrum and Aspergillus niger. UV- irradiation of drinking water has positive effect on most fungi (Kanzler et al., 2007) but the pigmented fungi resist UVtreatment.

Fungi can survive treatment and disinfection methods and most of single water treatment trials are not effective against all fungal species. So, in the present work combined treatment of drinking water by UV-irradiation followed by chlorination was carried out. 


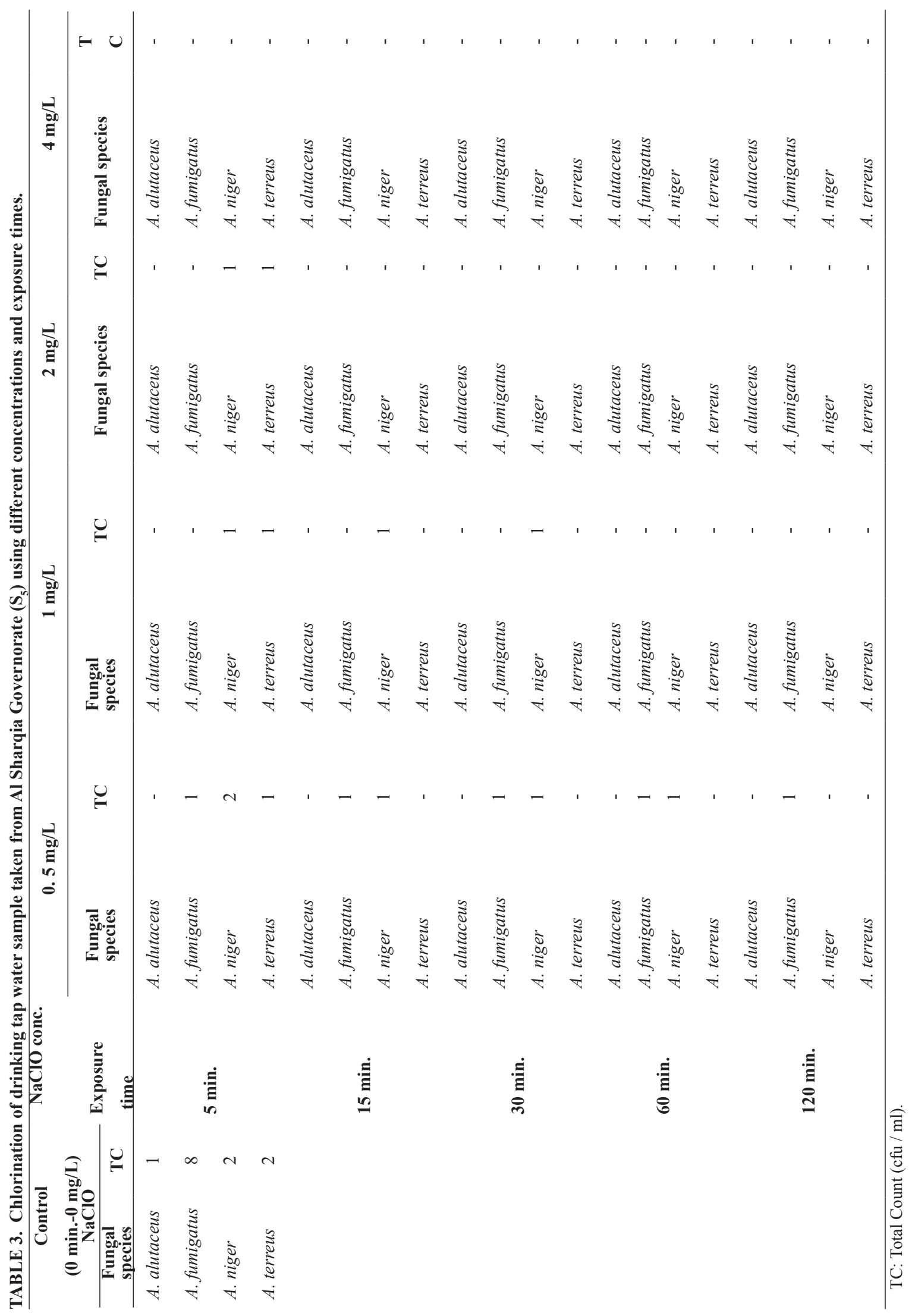

Egypt. J. Bot., 57, №.3 (2017) 
TABLE 4. UV-treatment of drinking tap water sample taken from Al Sharqia Governorate $\left(S_{5}\right)$.

\begin{tabular}{|c|c|c|c|c|c|c|c|c|}
\hline Fungal species & $\begin{array}{c}0 \\
\text { sec. }\end{array}$ & $\begin{array}{l}15 \\
\text { sec. }\end{array}$ & $\begin{array}{l}30 \\
\text { sec. }\end{array}$ & $\begin{array}{l}60 \\
\text { sec. }\end{array}$ & $\begin{array}{l}90 \\
\text { sec. }\end{array}$ & $\begin{array}{l}120 \\
\text { sec. }\end{array}$ & $\begin{array}{l}150 \\
\text { sec. }\end{array}$ & $\begin{array}{l}180 \\
\text { sec. }\end{array}$ \\
\hline Aspergillus alutaceus & 1 & 1 & - & - & - & - & - & - \\
\hline Aspergillus fumigatus & 8 & 1 & - & - & - & - & - & - \\
\hline Aspergillus niger & 2 & - & - & - & - & - & - & - \\
\hline Aspergillus terreus & 2 & 1 & 1 & - & - & - & - & - \\
\hline
\end{tabular}

Combination between UV-irradiationthen chlorination for $30 \mathrm{~min}$ (Table 5) proved to be most favorable than single treatment by any of them. Minimum concentration of $\mathrm{NaClO}(0.125$ $\mathrm{mg} / \mathrm{L})$ and minimum UV exposure time $(15 \mathrm{sec})$ were required to completely eliminate the fungal contamination from water sample.

TABLE 5. Combined treatment of drinking tap water sample collected from Al Sharqia governorate $\left(S_{5}\right)$ using UV irradiation followed by chlorination.

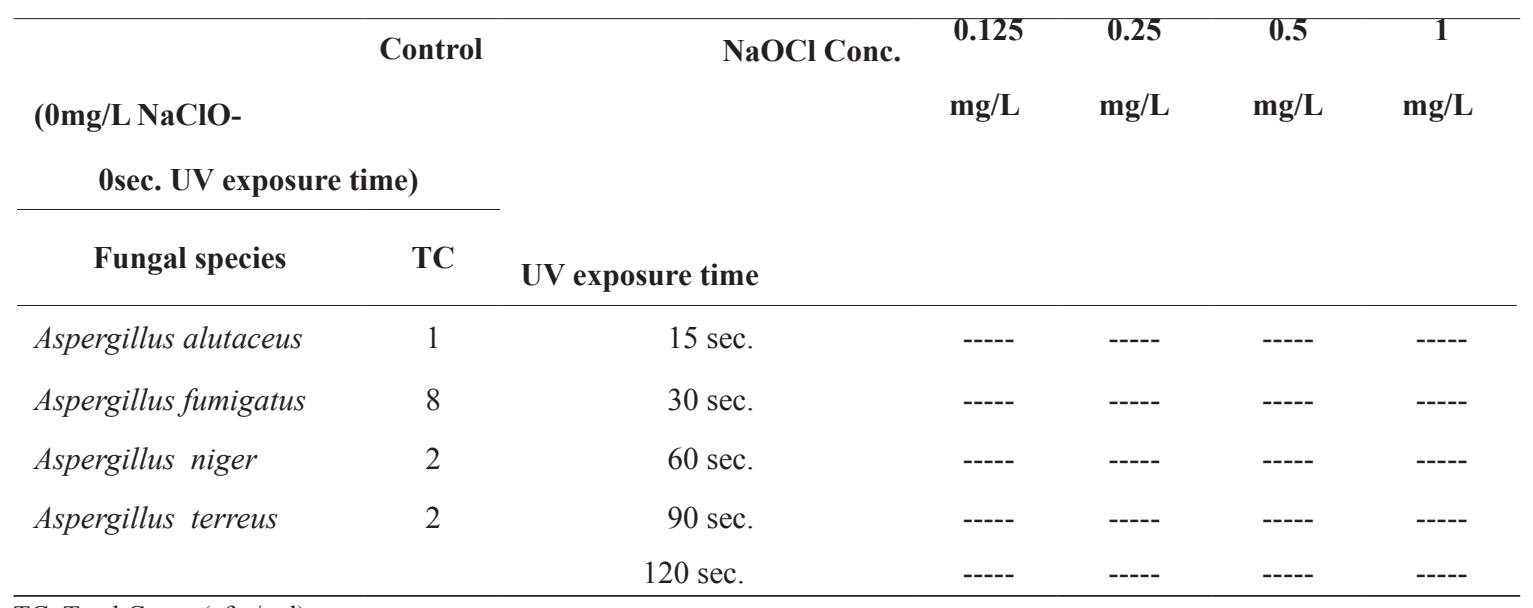

TC: Total Count (cfu / ml)

In relation to our results, Kelly et al. (2003) found that combined use of chlorine and ozone was highly effective against fungi in water than single treatment by any of them. Combined treatment by UV and chlorination increased the effectiveness against water fungi (Kanzler et al., 2007).

Generally, fungal infection of tap water may be aerosolized in air of indoor environment when water passed through showers, toilets cisterns which can cause allergy and respiratory disorders (Green et al., 2003). Fungi may form biofilm in drinking water pipe surfaces or in sediments in the distribution systems and on the filters of treatment plants which reduce its efficiencies and protect fungi against treatments (Hageskal et al., 2006).

\section{References}

Al Gabr, H.M., Zheng, T. and Yu, X. (2013) Inactivation of Aspergillus flavus in drinking water after treatment with UV irradiation followed by chlorination. Science of the total Environment, 463-464, 525 - 529.

Anaissie, E.J., Kuchar, R.T., Rex, J.H., Francesconi, A., Kasai, M., Müller, F.M.C., Mario, L.C., Summerbell, R.C., Dignani, M.C., Chanock, S.J. and Walsh, T.J. (2001) Fusariosis associated with pathogenic Fusarium species colonization of a hospital water system: A new paradigm for the epidemiology of opportunistic mold infections. Clinical Infectious Diseases, 33 (11), 1871-1878.

Arvanitidou, M., Kanellou, K., Katsouyannopoulos, V. and Tsakris, A. (2002) Occurrence and densities of fungi from northern Greek coastal 
bathing waters and their relation with faecal pollution indicators. Water Research, 36(20), 5127-5131.

Baron, J.L., Vikram, A., Duda, S., Stout, J.E. and Bibby, K. (2014) Shift in the microbial ecology of a hospital hot water system following the introduction of an on-site monochloramine disinfecion system. PLOS ONE, 9(7), e102679.

Begum, M., Hocking, A.D. and Miskelly, D. (2009) Inactivation of food spoilage fungi by ultraviolet (UVC) irradiation. International Journal of Food Microbiology, 129, 74 - 77.

Bucheli, T.D., Wettstein, F.E., Hartmann, N., Erbs, M., Vogelgsang, S., Forrer, H.R. and Schwarzenbach, R.P. (2008) Fusarium mycotoxins: Overlooked aquatic micro-pollutants?. Journal of Agricultural and Food Chemistry, 56(3), $1029-1034$.

Cabral, D. and Pinto, V.E.F. (2002) Fungal spoilage of bottled mineral water. International Journal of Food Microbiology, 72, 73 - 76

Codony, F., Morato, J. and Mas, J. (2005) Role of discontinuous chlorination on microbial production by drinking water biofilms. Water Research, 39, 18961906.

De Hoog, G.S., Guarro, J., Gene, J. and Figueras, M.J. (Ed.) (2004) "Atlas of Clinical Fungi". Centraalbureau voor Schimmelcultures.

Denning, D.W., O’Driscoll, B.R., Hogaboam, C.M., Bowyer, P. and Niven, R.M. (2006) The link between fungi and severe asthma: A summary of the evidence. European Respiratory Journal, 27, 615 - 626.

Dogget, M.S. (2000) Characterization of fungal biofilms within a municipal water distribution system. Applied and Environmental Microbiology, 66(3), 1249 - 1251.

Domingo, J.W.S., Ashbolt, N.J. and Rice, E.W. (2015) Drinking water, reference module in biomedical science. Website http://dx.doi.org/10.1016/B978-0-12801238-3.02247-9. Elsevier Inc.

Fountoulakis, M.S., Dokianakis, S.N., Kornaros, M.E., Aggelis, G.G. and Lyberatos, G. (2002) Removal of phenolics in olive mill wastewaters using the white-rot fungus Pleurotus ostreatus. Water Research, 36(19), $4735-4744$

Frankovà, E. and Horecka, M. (1995) Filamentous soil fungi and un-identified bacteria in drinking water from wells and water mains near Bratislava. Microbiological, 150, 311 - 313 .
Galal-Gorchev, H. (1996) Chlorine in water disinfection. Pure and Applied Chemistry, 68(9), 1731 - 1735.

Göttlich, E., Van der Lubbe, W., Lange, B., Fiedler, S., Melchert, I., Reifenrath, M., Flemming, H.C. and Hoog, S.D. (2002) Fungal flora in groundwaterderived public drinking water. International Journal of Hygiene and Environmental Health, 205, 269 - 279.

Green, B.J., Mitakakis, T.Z. and Tovey, E.R. (2003) Allergen detection from 11 fungal before and after germination. J. Allergy Clin. Immunol. 111, 285 - 289.

Hageskal, G., Knutsen, A.K., Gaustad, P., de Hoog, G.S. and Skaar, I .(2006) Diversity and significance of mold species in Norwegian drinking water. Applied and Environmental Microbiology, 72, 7587 - 7593.

Hageskal, G., Gaustad, P., Heier, B.T. and Skaar, I. (2007) Occurrence of molds in drinking water. Journal of Applied Microbiology, 102(3), 774 - 780.

Hageskal, G., Vrålstad, T., Knutsen, A.K. and Skaar, I. (2008) Exploring the species diversity of Trichoderma in Norwegian drinking water systems by DNA barcoding. Molecular Ecology Resources, 8, 1178 1188 .

Hageskal, G., Lima, N. and Skaar, I. (2009) The study of fungi in drinking water. Mycological Research, 113, $165-172$.

Junghanns, C., Moeder, M., Krauss, G., Martin, C. and Schlosser, D. (2005) Degradation of the xenoestrogen nonylphenol by aquatic fungi and their laccases. Microbiology, 151, 45 - 57.

Kanzler, D., Buzina, W., Paulitsch, A., Haas, D., Platzer, S., Marth, E. and Mascher, F. (2007) Occurrence and hygienic relevance of fungi in drinking water. Mycosis, 51, $165-169$.

Kelly, J., Kinsey, G., Paterson, R. and Brayford, D. (2003) Identification and control of fungi in distribution systems. Awwa Research Foundation and American Water Works Association, Denver, Co.

Kim, J., Chung, Y., Shin, D., Kim, M., Lee, Y. and Lim, Y. (2002) Chlorination by-products in surface water treatment process. Desalination, 151, 1 - 9 .

King, D.N., Donohue, M.J., Vesper, S.J., Villegas, E.N., Ware, M.W., Vogel, M.E., Furlong, E.F., Kolpin, D.W., Glassmeyer, S.T. and Pfaller, S. (2016) Microbial pathogens in source and treated waters from drinking water treatment plants in the United States and implications for human health. Science of the Total Environment, 562, 987-995. 
Kirk, P.M., Cannon, P.F., David, J. and Stalpers, J.A. (2001) "Ainsworth \& Bisby's Dictionary of the Fungi", $9^{\text {th }}$ ed. $\mathrm{CAB}$ International, Wallingford.

Ma, X. and Bibby, K. (2017) Free chlorine and monochloramine inactivation kinetics of Aspergillus and Penicillium in drinking water. Water Research, 120, 265-271.

Mara, D. and Horan, N. (2006) "The Handbook of Water and Wastewater Microbiology", $1^{\text {st }}$ ed. Elsevier Academic Press, London.

Memon, N.A. (2012) Isolation of fungi in the drinking water distribution system of Hyderabad (Pakistan). Quaid-e-Awam University Research Journal of Engineering, Science and Technology, 11, 1.

Moubasher, A.H. (1993) "Soil Fungi in Qutar and Arab Countries". The Center for Scientific and Research, University of Qatar, Qatar.

Nagy, L.A. and Olson, B.H. (1985) Occurrence and significance of bacteria, fungi and yeasts associated with distribution pipe surfaces. In: Proceedings of the American Water Works Association, Water Quality Technical Conference. American Water Works Association, Denver, CO, pp. 213 - 238.

Nourmoradi, H., Nikaeen, M., Stensvold, C.R. and Mirhendi, H. (2012) Ultraviolet irradiation: An effective inactivation method of Aspergillus spp. in water for the control of waterborne nosocomial aspergillosis. Water Research, 4(6), 5935-5940.

Oliveira, B.R., Crespo, M.T.B., Romão, M.V.S., Benoliel, M.J., Samson, R.A. and Paterson, R.R.M. (2013) Fungi and fungal toxins as weapons. Mycological Research, 110, $1003-1010$.

Paterson, R.R.M., Kelley, J. and Gallagher, M. (1997) Natural occurrence of aflatoxins and Aspergillus flavus (Link) in water. Letters in Applied Microbiology, 25, 435-436.

Paterson, R.R.M., Goncalves, A.B. and Lima, N. (2006) Mycological examination and biofilm formation in drinking water. In: Proceedings of the $8^{\text {th }}$ International Mycological Congress. SAPMEA, Eastwood, Australia, pp. 129.

Pereira, V.J. (2013) New insights concerning the occurrence of fungi in water sources and their potential pathogenicity. Water Research, 47, 6338 - 6347.

Pereira, V.J., Bacilio, M.C., Fernandes, D., Domingues, M., Paiva, J.M., Benoliel, M.J., Crespo, M.T.B and Romão, M.V.S (2009) Occurrence of filamentous fungi and yeast in three different drinking water sources. Water Research, 43, 3813-3819.

Pereira, V.J., Fernandes, D., Carvalho, G., Benoleil, M.J., Romão, M.V.S. and Crespo, M.T.B. (2010) Assessment of the presence and dynamics of fungi in drinking water sources using culture and molecular methods. Water Research, 44, 4850 - 4859.

Pereira, V.J., Marques, R., Marques, M., Benoliel, M.J. and Crespo, M.T.B. (2013) Free chlorine inactivation of fungi in drinking water sources. Water Research, 47, $517-523$.

Rosenzweig, W.D., Minnigh, H.A. and Pipes, W.O. (1983) Chlorine demand and inactivation of fungal propagules. Applied and Environmental Microbiology, 45(1), 182 - 186.

Schüßler, A., Schwarzott, D. and Walker, C. (2001)A new fungal phylum, the Glomeromycota: phylogeny and evolution. Mycological Research, 105, 1413-1421.

Skaar, I. and Østensvik, Ø. (2005) Moulds in water from Oset and Skullerud waterworks (in Norwegian). Report from Oslo Water and Sewerage Works, Oslo.

Sonigo, P., De Toni, A. and Reilly, K. (2011) A review of fungi in drinking water and the implication for human health. Defra, Department for Environment Food and Rural Affairs.

Spreadbury, C., David, H., Agnes, A.B., Bainbridge, B. and Cohen, J. (1993) Detection of Aspergillus fumigatus by polymerase chain reaction. J. Clin. Microbiol. 31, 615-621.

Straus, D.C. (2004) Sick building syndrome. Advances and Applied Microbiology, 55, 3-473.

Warris, A., Gaustad, P., Meis, J.F.G.M., Voss, A., Verweij, P.E. and Abrahamsen, T.G. (2001) Recovery of filamentous fungi from water in a paediatric bone marrow transplantation unit. Journal of Hospital Infection, 47, 143 - 148.

Yamaguchi, M.U., Rampazzo. R.C.P, Yamada-Ogatta, S.F., Nakamura, C.V., Ueda-Nakamura, T. and Filho, B.P.D. (2007) Yeasts and filamentous fungi in bottled mineral water and tap water from municipal supplies. Brazilian Archives of Biology and Technology, 50(1), $1-9$.

Yan, G. and Viraraghavan, T. (2003) Heavy-metal removal from aqueous solution by fungus Mucor rouxii. Water Research, 37(18), 4486 - 4496.

(Received 15 / 5 /2017; accepted 17 / $10 / 2017$ ) 


\title{
تواجد الفطريات في مصادر مياه الثرب ومعالجتها بواسطة الكلور والأشعة الفوق بنفسجية
}

\author{
إيمان عبد الله محمد علي، تهاني محمد علي عبد الرحمن، محسن أبو العلا سيد و سمر حسني عبد الخالق
}

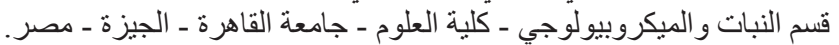

وجد أن إجمالي عدد الأنواع الفطرية كان 45 وحدة تكوين مستعمرة في 1 ملليلتر من المياه نم عزلهي لهم من 9

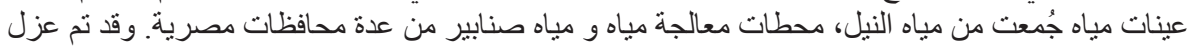

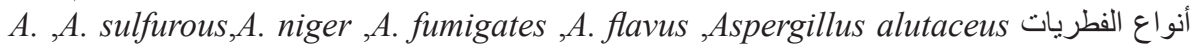
Trichoderma viride ,P. globrum, Penicillum crysogenum ,terreus

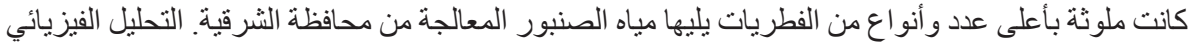

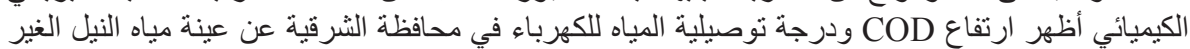

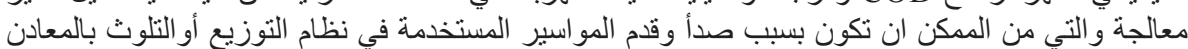

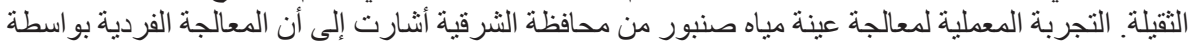

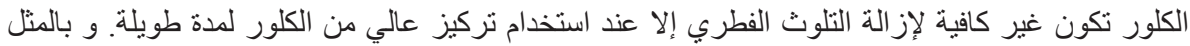

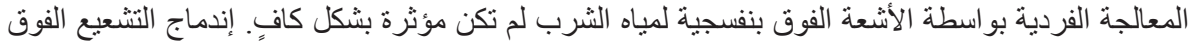

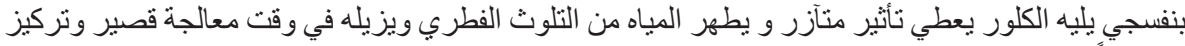

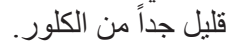

